\title{
Catharanthus roseus, an Experimental Host Plant for the Citrus Strain of Xylella fastidiosa
}

\author{
P. B. Monteiro, Fundo de Defesa da Citricultura (Fundecitrus), Av. Dr. Adhemar Pereira de Barros, 201, 14807- \\ 040, V. Melhado, Araraquara, SP, Brazil, J. Renaudin, S. Jagoueix-Eveillard, Laboratoire de Biologie Cellulaire \\ et Moléculaire (LBCM), IBVM, INRA, Bordeaux B.P.81, 33883 Villenave d'Ornon Cedex, France, A. J. Ayres, \\ Fundo de Defesa da Citricultura (Fundecitrus), Av. Dr. Adhemar Pereira de Barros, 201, 14807-040, V. Melhado, \\ Araraquara, M. Garnier, and J. M. Bové, Laboratoire de Biologie Cellulaire et Moléculaire (LBCM), IBVM, \\ INRA, Bordeaux B.P.81, 33883 Villenave d'Ornon Cedex
}

\begin{abstract}
Monteiro, P. B., Renaudin, J., Jagoueix-Eveillard, S., Ayres, A. J., Garnier, M., and Bové, J. M. 2001. Catharanthus roseus, an experimental host plant for the citrus strain of Xylella fastidiosa. Plant Dis. 85:246-251.

We verified by pathogenicity tests that the herbaceous plant Catharanthus roseus (Madagascar periwinkle) can be used as an experimental host for the strain of Xylella fastidiosa that causes citrus variegated chlorosis (CVC). Plants were mechanically inoculated with CVC strain $9 \mathrm{a} 5 \mathrm{c}$, the genome of which was recently sequenced. Plants were inoculated with the virulent 8th passage $(9 a 5 c-8)$ and the 51st passage $(9 a 5 c-51)$. Leaf deformation and stunting were seen 2 months after inoculation on 18 of 21 plants with $9 a 5 c-8$ and 8 of 21 plants with $9 a 5 c-51$. The plants were infected with $X$. fastidiosa as shown by polymerase chain reaction. The bacterium could be reisolated from all plants tested, showing that CVC- $X$. fastidiosa multiplied and moved systemically in $C$. roseus plants causing dysfunction in plant growth. The disease symptoms evolved within 4 months post-inoculation to a severe leaf chlorosis in all inoculated plants. The localization of $X$. fastidiosa in the xylem was verified by immunofluorescence. Genes coding for proteins with homologies to plant sterol-C-methyltransferase, a transketolase-like protein, subunit III of photosystem I, and a desiccation protectant protein were found to be differentially expressed in symptomatic $C$. roseus plants as a response to infection with $X$. fastidiosa in comparison to healthy plants. A tentative correlation between the pattern of expression of these $C$. roseus genes with the mechanism of pathogenicity of $X$. fastidios $a$ is discussed.
\end{abstract}

Xylella fastidiosa is a fastidious Gramnegative, xylem-limited bacterium (28). In many economically important plants, different groups of $X$. fastidiosa cause diseases such as citrus variegated chlorosis (CVC) $(4,25)$, periwinkle wilt (PW), and Pierce's disease (PD) of grapevine, alfalfa dwarf, leaf scorch of almond, coffee, elm, sycamore, oak, plum, mulberry, maple, and oleander $(22,23)$. The full host range of the bacterium is large and includes many asymptomatic herbaceous and woody plant species $(10,13)$. Strains of X. fastidiosa, however, are pathogenically specialized. For example it was shown that although both PD and PW strains of $X$. fastidiosa multiply in grapevine and periwinkle, the PW strain does not induce symptoms in grapevine, and the PD bacterium induced

Corresponding author: P. B. Monteiro

E-mail: pbmonteiro@fundecitrus.com.br

Accepted for publication 18 October 2000.

Publication no. D-2001-0102-02R

(C) 2001 The American Phytopathological Society only slight chlorosis in periwinkle but not typical PW symptoms (8).

$X$. fastidiosa isolated from different hosts have been separated into groups by several approaches including random amplified polymorphic DNA (RAPD), restriction fragment length polymorphism (RFLP), by polymerase chain reaction (PCR) using tRNA consensus primers or strain specific primers or by subtractive hybridization $(1,2,6,9,20,21)$.

$\mathrm{CVC}$ is a major problem in the state of São Paulo, Brazil, where over 60 million trees $(30 \%)$ are affected. It occurs in Argentina where it is called "pecosita" $(7,12)$. Rapid dissemination of CVC comes from the use of infected nursery trees and transmission of $X$. fastidiosa by several sharpshooter vectors. In Brazil X. fastidiosa is also associated with plum leaf scald $(11,15)$ and coffee leaf scorch $(3,17,19)$, and was recently detected in Catharanthus roseus (Madagascar periwinkle) showing stunting and dieback symptoms (27). The strains isolated from coffee and citrus are closely related $(3,17,19,24)$, whereas the plum strain is distantly related (24). The strain isolated from $C$. roseus in Brazil is still uncharacterized.
Periwinkle genes are differentially expressed following infection with phloemrestricted pathogens Spiroplasma citri or the stolbur phytoplasma (14, JagoueixEveillard, S., Tarendeau, F., Guolter, K., Danet, J. L., Bové, J. M., and Garnier, M. unpublished data) which cause diseases in many different plants, inducing yellowing, growth aberrations, flower malformation, internode shortening, and stunting. cDNAs corresponding to these genes were used as probes for northern-blot analysis studying the reaction of periwinkle to infection with $X$. fastidiosa, a xylem-restricted pathogen. These cDNAs code for proteins with homologies to plant sterol-C-methyltransferase (SMT), a transketolase-like protein (TLK), subunit III of photosystem I, and a desiccation protectant protein, respectively (14, Jagoueix-Eveillard, S., Tarendeau, F., Guolter, K., Danet, J. L., Bové, J. M., and Garnier, M., unpublished data). SMT is a rate-limiting enzyme for the phytosterol biosynthesis, which plays multiple roles in plant growth and development. TLK is involved in both the Calvin cycle and the oxidative pentose phosphate pathway (OPP) of higher-plant chloroplasts, synthesizing different sugar phosphate intermediates. The subunit III of photosystem I has a function in the photosynthetic pathways and the desiccation protectant protein is involved in plant cellular protection strategy to tolerate water deficiency.

C. roseus is a symptomatic host for the citrus strain of $X$. fastidiosa and may be useful for experimental studies. We have used strain 9a5c, whose genome was recently sequenced (26). This strain was triply cloned and shown to be phytopathogenic in sweet orange seedlings (16). For post-genomic studies, it was essential to obtain an experimental host that is easier to use than citrus and which develops symptoms faster than sweet orange seedlings. We tested the 8th passage of strain 9a5c (9a5c-8), known to be phytopathogenic, and also the 51st passage (9a5c-51), to evaluate the effect of prolonged subculturing of the CVC strain of $X$. fastidiosa on phytopathogenicity. 


\section{MATERIALS AND METHODS}

Subculturing CVC-X. fastidiosa 9a5c strain. The triply cloned strain 9a5c (16) was grown in $\mathrm{PW}$-broth medium at $28^{\circ} \mathrm{C}$ in the dark with $100 \mathrm{rpm}$ rotatory agitation. The initial culture was passaged weekly by serial transfers at $1 / 100$ dilution. Dilution plating on PW agar medium (six 10-fold dilutions) was used to estimate the number of viable bacterial cells (colony forming units, CFU) and confirm freedom from contamination. The plates, sealed with Parafilm to prevent desiccation, were incubated at $28^{\circ} \mathrm{C}$ in the dark for 6 to 14 days. Cultures were stored at $-20^{\circ} \mathrm{C}$ in PW broth containing $20 \%$ glycerol.

Mechanical inoculation of plants. Catharanthus roseus (L.) G. Don (cv. Pep-

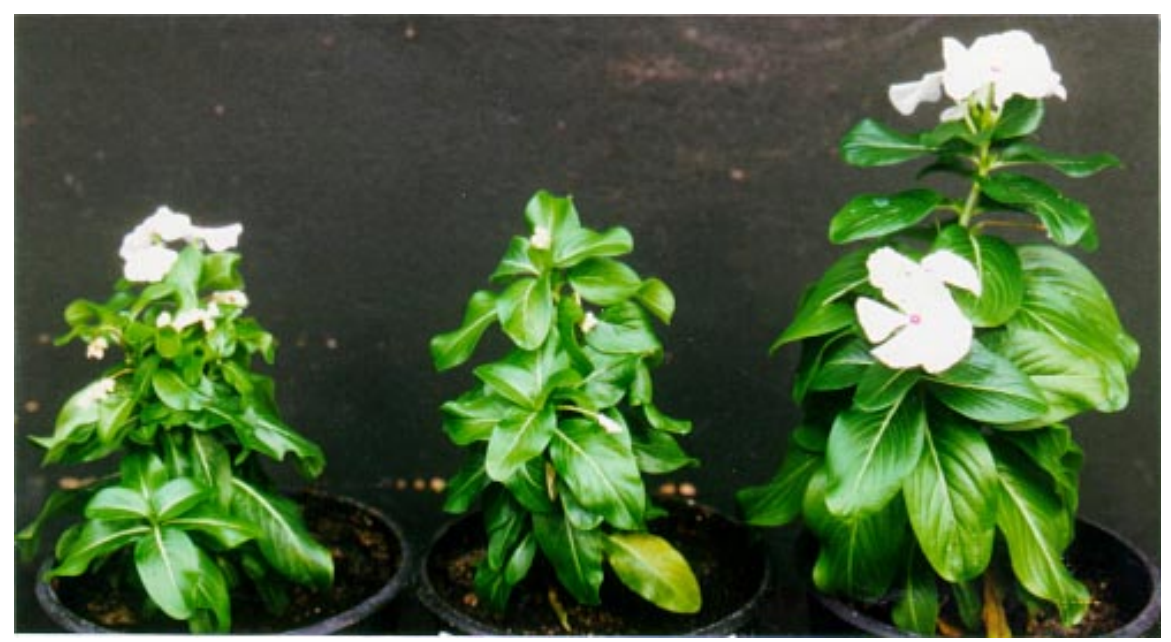

Fig. 1. Catharanthus roseus plants 2 months after inoculation with $9 \mathrm{a} 5 \mathrm{c}-8$ (left) and $9 \mathrm{a} 5 \mathrm{c}-51$ (middle) in comparison with the phosphate-buffered saline-mock inoculated plant (right). Symptoms are stunting and leaf deformation.
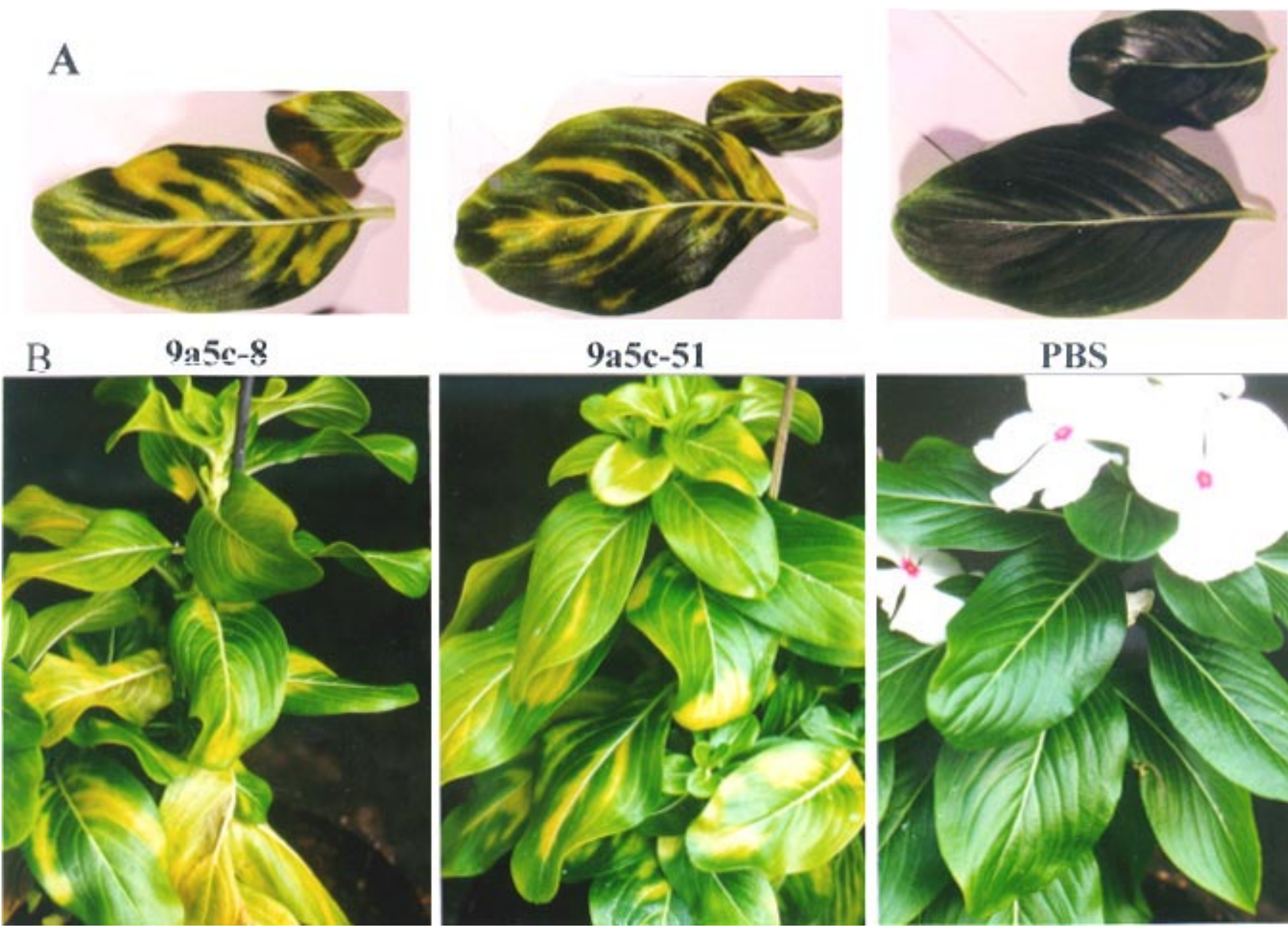

permint Cooler) was used as the experimental host plant. Plants were propagated by seeds and grown in an insect-proof greenhouse. Three days before inoculation, the plants were transferred from the greenhouse to the culture room, with a photoperiod of $14 \mathrm{~h}$ light at $28^{\circ} \mathrm{C}$ and $10 \mathrm{~h}$ dark at $18^{\circ} \mathrm{C}$. Inoculations were done after $5 \mathrm{~h}$ of light $\left(\right.$ at $28^{\circ} \mathrm{C}$ ) ensuring xylem tension and good liquid uptake.

A 7-day-old broth culture (late $\log$ phase) of $X$. fastidiosa was centrifuged at $4,000 \times g$ for $15 \mathrm{~min}$ and the resulting pellet resuspended in sterile phosphate-buffered saline (PBS) $(20 \mathrm{mM}$ sodium phosphate, $\mathrm{pH} 6.8,0.85 \% \mathrm{NaCl}$ ) at an $\mathrm{OD}_{560 \mathrm{~nm}}$ of 0.1 , corresponding to approximately $10^{8}$ $\mathrm{CFU} / \mathrm{ml}$. This correlation was obtained from a growth curve of $X$. fastidiosa in liquid medium, in which the number of CFU was obtained by dilution plating and $A_{560 \mathrm{~nm}}$ readings were taken at different phases of the culture as a function of time.

Two 1-cm-long inverted-U-shaped incisions were made with a scalpel on opposite sides in the second internode from base of the stem of 11-week-old periwinkle plants (15 cm high). A unit of $20 \mu \mathrm{l}$ of the prepared suspension of $X$. fastidosa was deposited on each incision. The drop was then allowed to enter in the xylem by 6 repeated punctures with a needle. An addi-

Fig. 2. A, Mature leaves from diseased Catharanthus roseus plants shown in $\mathbf{B}, 4$ months post-inoculated with $9 \mathrm{a} 5 \mathrm{c}-8$ and $9 \mathrm{a} 5 \mathrm{c}-51$ in comparison with healthy phosphate-buffered saline-mock inoculated plant. 
tional $20 \mu \mathrm{l}$ aliquot of cell suspension was added on the wounded stem and allowed to be absorbed. After inoculation, the bark strips were flipped back on the scion and sealed by gentle finger pressure. In addition, the closest pair of leaves immediately above the inoculation site was also inoculated; a unit of $20 \mu \mathrm{l}$ of $X$. fastidosa suspension was pipetted on the upper surface of the petioles, and allowed to be absorbed by pin-holes, punched into the petioles. Control plants were inoculated in the same way with PBS or left untreated. Inoculated and control plants were kept in the culture room and watered every 3 days. Twentyone plants were mechanically inoculated with the 8th and 51st passages of CVC strain $9 \mathrm{a} 5 \mathrm{c}$, originally obtained from the axenic culture 8.1 by triple cloning (4).

Reisolation of $X$. fastidiosa from inoculated Catharanthus roseus. The four terminal leaves of 4 months postinoculated plants were washed in water, and dried with blotting paper. The subsequent procedures were done under aseptical conditions in a laminar-flow hood.
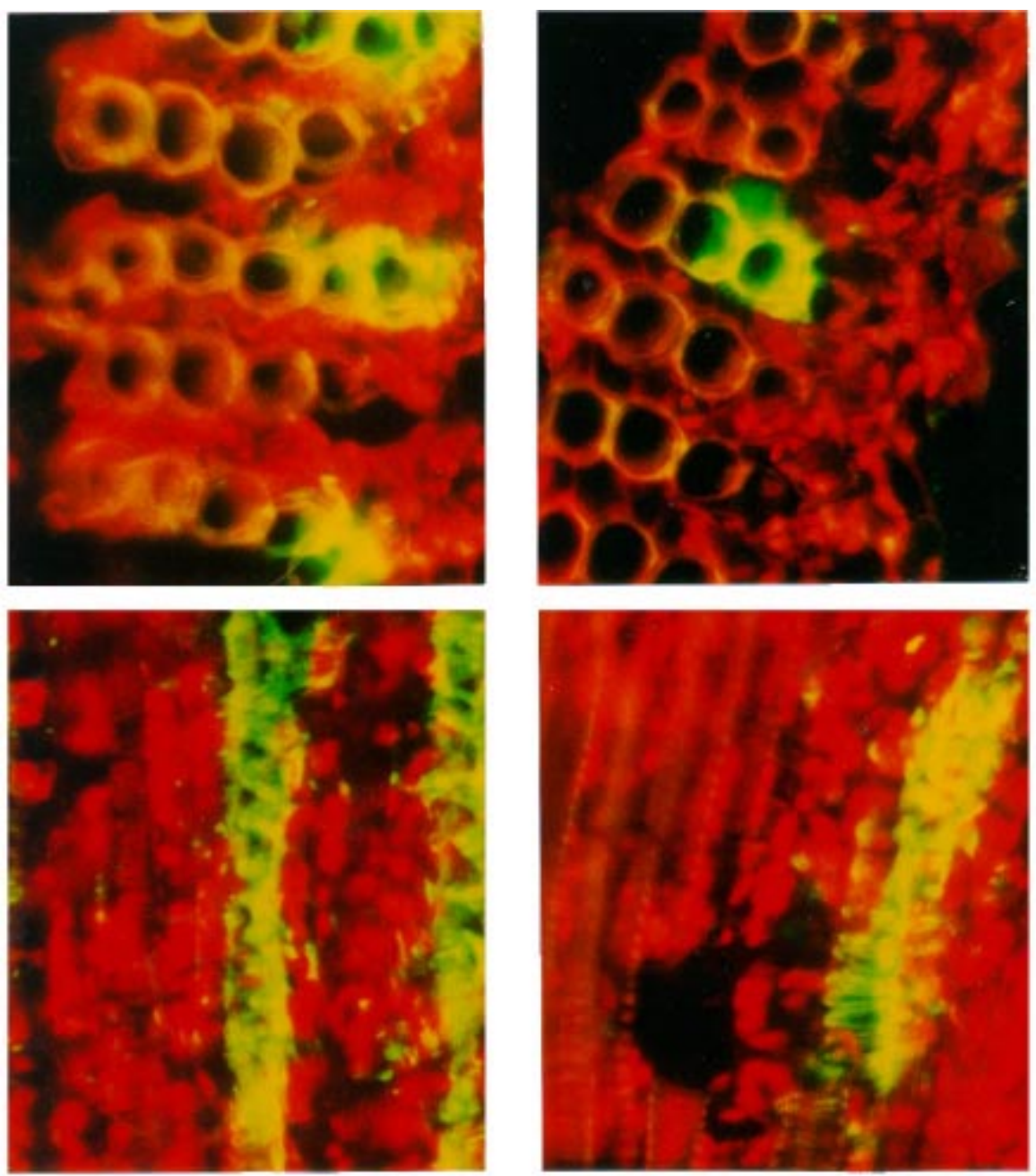

A
Periwinkle leaf petioles and midribs were excised and drops of melted paraffin deposited at both ends. Plant material was surface sterilized by immersion in $70 \%$ ethanol for $4 \mathrm{~min}$ and $6 \%$ sodium hypochlorite for $15 \mathrm{~min}$ under agitation. Midribs were rinsed five times with sterile deionized water. For extraction of the xylem sap, the edges of the disinfected petioles and midribs were cut off, removing the paraffin, and tightly packed into a 0.5 $\mathrm{ml}$ sterile eppendorf tube with a $1 \mathrm{~mm}$ hole in the bottom and inserted into a $1.5 \mathrm{ml}$ eppendorf tube. Each set of two eppendorf tubes was transferred aseptically to a $15 \mathrm{ml}$ tube. A unit of $200 \mu$ l of PW medium was added on top of the plant material, the tubes were centrifuged at $4,000 \times g$ for 15 min at room temperature extracting the xylem sap. The pellet was resuspended in 1 $\mathrm{ml}$ PW medium, $200 \mu \mathrm{l}$ were plated on PW agar medium and the remaining suspension was incubated at $28^{\circ} \mathrm{C}$. Plates were observed for colony development at 4-day intervals for 15 days with a binocular microscope ( $\times 10$ magnification). The char-

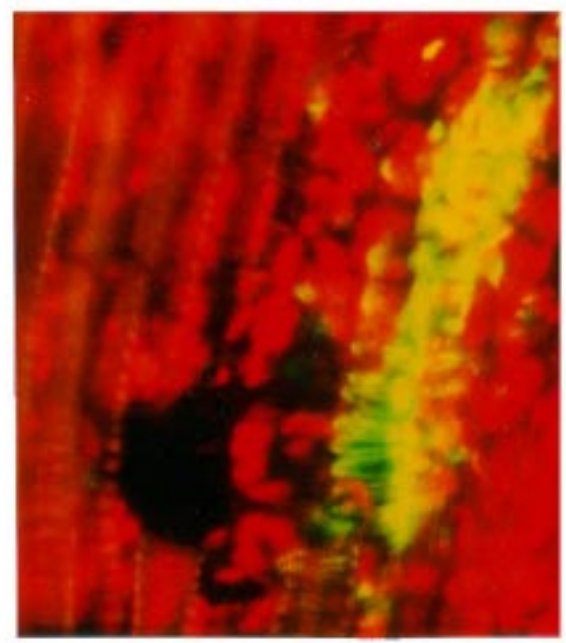

B acteristic appearance, growth rate, and growth pattern of colonies on PW agar medium and the characteristic growth in liquid PW were regarded as preliminary indications of $X$. fastidiosa growth. Final identification of the bacteria as $X$. fastidiosa was by PCR and immunoblotting as described below.

PCR. We followed the conditions for PCR as described (21), using primers CVC-1 and 272-2 int for the specific detection of the CVC strain of $X$. fastidiosa. For the detection of $X$. fastidiosa in the xylem sap of inoculated plants, bacterial cells were collected by centrifuging the petioles and midribs of three leaves situated two or three nodes above the inoculation sites $(15,000 \times g$ for $10 \mathrm{~min})$, as described above for the culturing of $X$. fastidiosa. After centrifugation, the pellets were air-dried under vacuum for $5 \mathrm{~min}$ and resuspended in $100 \mu \mathrm{l}$ of TE $(10 \mathrm{mM}$ Tris, $10 \mathrm{mM}$ EDTA, $\mathrm{pH}$ 8.0). The suspension was incubated at $65^{\circ} \mathrm{C}$ for $15 \mathrm{~min}$ and $1 \mu \mathrm{l}$ was transferred directly to $20 \mu \mathrm{l}$ of PCR reaction mixture. For the identification of
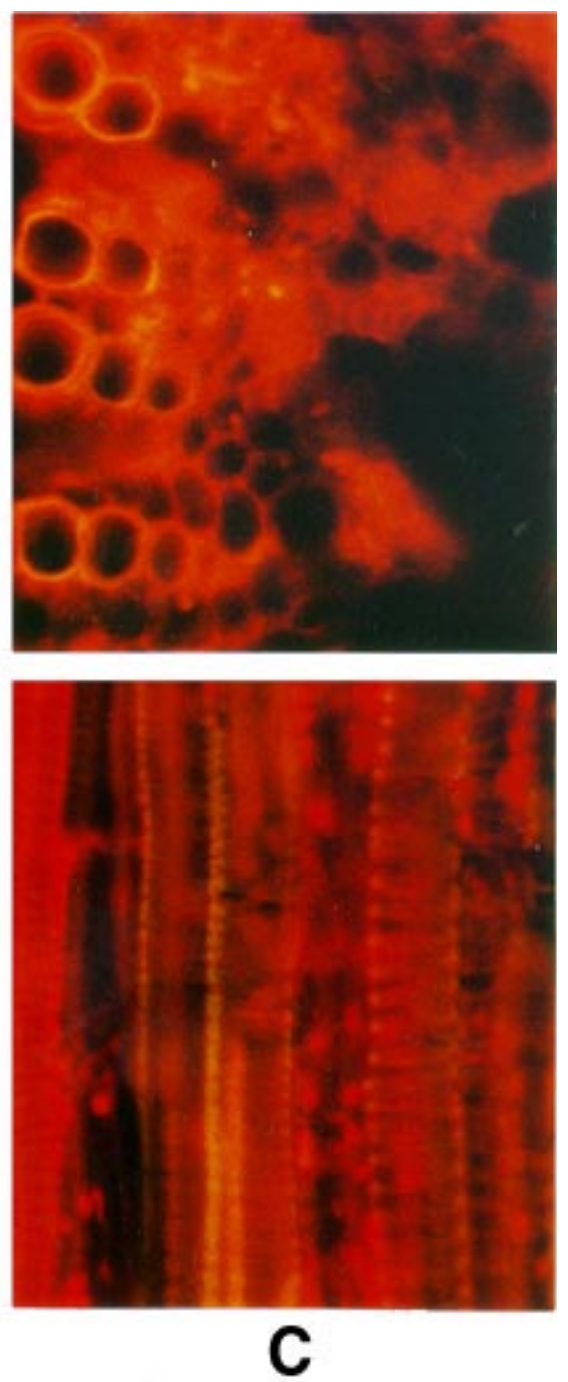

Fig. 3. Immunofluorescence with polyclonal antibody anti-citrus variegated chlorosis strain of Xylella fastidiosa on transversal (top) and longitudinal (bottom) sections of leaf midribs from Catharanthus roseus plants infected with A, 9a5c-8; B, 9a5c-51; and $\mathbf{C}$, and mock inoculated with phosphatebuffered saline $(\times 1,000)$. 
$X$. fastidiosa in culture, $1 \mu \mathrm{l}$ of the suspension or a single colony was added directly to the PCR reaction mixture. As positive control, we used $50 \mathrm{ng}$ of $X$. fastidiosa DNA prepared as described (5) with the difference that, after the lysis with lysozyme, the preparation was treated with $0.5 \%$ sodium dodecyl sulfate (SDS) and $0.1 \mathrm{mg} / \mathrm{ml}$ proteinase $\mathrm{K}$ for $1 \mathrm{~h}$ at $60^{\circ} \mathrm{C}$.

Immunoblot detection of $X$. fastidiosa. The colonies were transferred to a nitrocellulose membrane and treated with a $1 / 10,000$ dilution of a polyclonal antiserum produced against the CVC strain 8.1.b of $X$. fastidiosa (12). A commercial antirabbit IgG/alkaline phosphatase conjugate (Sigma) was used as the secondary antibody. For development, we followed the instructions of the conjugate supplier. Colonies of $E$. coli were used as the negative control.

Immunofluorescence. Longitudinal or transversal $30 \mu \mathrm{m}$ thick sections of midribs cut from healthy or symptomatic young leaves were mounted on microscope slides, fixed by heating at $45^{\circ} \mathrm{C}$ for $45 \mathrm{~min}$, and incubated for $30 \mathrm{~min}$ at room temperature with a 200-fold dilution of an immunoglobulin fraction purified from the CVCstrain specific polyclonal antiserum according to Garnier et al. (12). After incubation, the slides were rinsed with PBSTween and incubated in the dark with a 10,000-fold dilution of anti-rabbit mouseIgGs labeled with fluorescein isothiocyanate (IgG-FITC). The diluted IgG-FITC solution was prepared by adding $10 \mu$ of the commercial IgG-FITC (Diagnostic Pasteur) to $1 \mathrm{ml}$ of PBS containing $10 \mu \mathrm{l}$ of commercial solution of Evans blue (Diagnostic Pasteur). After washing with PBS-Tween, a mounting solution (22.2 $\mathrm{mM}$ citric acid, $55.6 \mathrm{mM} \mathrm{Na} \mathrm{PO}_{4}, 50 \%$ glycerol) was added and the slides were observed using a Zeiss III RS fluorescent microscope with the filter combination $\mathrm{PB}$ 455/490 FT510/LP 520.

Northern blot analysis. For RNA isolation, eight young terminal leaves of each control or infected plant 4 months after inoculation were ground in liquid nitrogen with a mortar and pestle, the powder was treated with Tryzol (Gibco-BRL) according to the supplier, and $15 \mu \mathrm{g}$ of total RNA was submitted to electrophoresis on a $1.2 \%$ agarose gel containing $5 \%$ formaldehyde and $10 \% 3$-(N-Morpholino) propanesulfonic acid (MOPS). RNA samples were prepared in $65 \%$ formamide, $22 \%$ formaldehyde, $13 \%$ MOPS containing 10 $\mu \mathrm{g} / \mathrm{ml}$ ethidium bromide, and incubated for $10 \mathrm{~min}$ at $65^{\circ} \mathrm{C}$. One microliter of loading dye was added. After electrophoresis, the RNA was transferred to Hybond C-extra nitrocellulose membrane (Amersham) in $20 \times \mathrm{SSC}(3 \mathrm{M} \mathrm{NaCl}, 0.30 \mathrm{M} \mathrm{Na}$ citrate) and fixed by heating at $80^{\circ} \mathrm{C}$ for $2 \mathrm{~h}$. Prehybridization was performed at $42^{\circ} \mathrm{C}$ in a solution containing $5 \times \mathrm{SSC}, 50 \%$ formamide, $0.5 \%$ SDS, $5 \times$ Denhardt's solution,
$0.02 \mathrm{M}$ Tris $\mathrm{pH} 7.5$, and $0.3 \mathrm{mg} / \mathrm{ml}$ yeast tRNA. Hybridization was done in the same buffer containing $\alpha-{ }^{32} \mathrm{PdATP}-$ labeled probes. The probes obtained as DNA inserts from recombinant pGEM-T-easy plasmids were labeled by random priming according to the kit supplier (Gibco BRL). Membranes were washed 3 times in $2 \times \mathrm{SSC}, 0.5 \%$ $\mathrm{SDS}$ at room temperature for $10 \mathrm{~min}$ and in $0.1 \times \mathrm{SSC}, 0.1 \% \mathrm{SDS}$ at $50^{\circ} \mathrm{C}$ for $45 \mathrm{~min}$, before exposure to X-ray films.

The cDNAs probes code for the following putative periwinkle proteins: sterol-Cmethyltransferase (probe Sc 1), transketolase-like protein (probe Sc Q), subunit III of photosystem I (probe St C2), and desiccation protectant protein (probe Sc A11-1) (14, Jagoueix-Eveillard, S., Tarendeau, F., Guolter, K., Danet, J. L., Bové, J. M., and Garnier, M. unpublished data).

\section{RESULTS AND DISCUSSION}

Pathogenicity of $X$. fastidiosa CVC strain to $C$. roseus. Symptoms were observed two months after inoculation of the plants with $9 \mathrm{a} 5 \mathrm{c}-8$ or $9 \mathrm{a} 5 \mathrm{c}-51$. The first symptoms were noticeable as small and deformed young leaves as well as plant size reduction (Fig. 1). Eighteen of 21 plants inoculated with the 8th passage showed these symptoms; whereas, only 8 of 21 plants inoculated with the 51st passage developed the symptoms. The presence of $X$. fastidiosa was detected by PCR in petioles and midribs of leaves collected from nodes, $10 \mathrm{~cm}$ distant from the inoculation sites in all inoculated plants, both symptomatic and non symptomatic (results not shown). These results indicate that the early 8th passage as well as the later 51st passage of $9 \mathrm{a} 5 \mathrm{c}$ are able to multiply and become systemic in C. roseus within 2 months after inoculation. However, the percentage of symptomatic plants was higher with $9 \mathrm{a} 5 \mathrm{c}-8$ than with $9 \mathrm{a} 5 \mathrm{c}-51$. The 8th and the 15th passages of strain 9a5c were already shown to have kept the phytopathogenicity of the initial isolate $8.1 \mathrm{~b}$ to sweet orange seedling (16).

Four months after inoculation all inoculated plants, including those that did not show symptoms two months postinoculation, started showing marginal and chlorotic zones along the veins, most frequently in the older leaves (Fig. 2A and B). These leaves abscised early and, in extreme cases, most shoots retained only the most apical leaves. The severity of the symptoms was the same whether the plants were inoculated with $9 \mathrm{a} 5 \mathrm{c}-8$ or $9 \mathrm{a} 5 \mathrm{c}-51$ (Fig. 2). Immunofluorescence, however, showed that the number of xylem vessels containing green-fluorescing bacteria was higher in the plants infected with $9 \mathrm{a} 5 \mathrm{c}-8$ (Fig. 3A) than with 9a5c-51 (Fig. 3B). No green fluorescing material was observed in the xylem tissue of mock inoculated plants (Fig. 3C).

Six months post-inoculation, the infected plants were highly stunted. Young leaves in the apical shoots were highly deformed with rippled veins. Plants have been maintained in the culture room for longer than 12 months, but some plants wilted and died. This wilting occurs very late and is different from that reported for the PW strain (18). In addition, the PW strain has not been reported to induce young leaf deformation (18).

$X$. fastidiosa was reisolated by plating xylem sap extracted from plants inoculated with either $9 a 5 c-8$ or $9 a 5 c-51$ on PW-agar plates. Slow-growing bacterial colonies characteristic of $X$. fastidiosa were observed 13 days after plating. The colonies gave positive PCR reactions with the primers $\mathrm{CVC1} \times 272-2$ int and were recognized on immunoblots by the specific polyclonal antibody.

$X$. fastidios $a$ was recently isolated from naturally infected, diseased plants of $C$. roseus in Brazil showing stunting, dieback symptoms but no chlorosis (27). These symptoms differ from those described here.

The origin of the strain of $X$. fastidiosa infecting citrus is still unknown in Brazil. Alternative hosts of $X$. fastidiosa could act as sources for insect vector acquisition. Whether C. roseus and other weed hosts make a significant contribution to the incidence of CVC in Brazil has not been established. Genetic diversity analysis of $X$. fastidiosa isolated from $C$. roseus and other hosts would provide a clue for the mechanism of spread of CVC in Brazil. This information would be useful to forecast and potentially control the spread of this pathogen.

C. roseus is a symptomatic host plant for the CVC strain of $X$. fastidiosa. C. roseus should be a convenient experimental host plant, since symptoms develop in $100 \%$ of infected plants which was not reported to be accomplished with mechanical inoculated citrus. In addition, the symptoms develop faster in $X$. fastidiosa infected $C$. roseus than in sweet orange seedlings (16). Pathogenicity tests in C. roseus plants should be useful for the screening of nonpathogenic mutants of CVC-X. fastidiosa.

Pattern of gene expression in $C$. roseus infected with $X$. fastidiosa $\mathrm{CVC}$ strain. The technique of differential display can be used to study how expression of plant genes is affected by infection with a given pathogen. In this way, several $C$. roseus cDNAs were identified which are differentially expressed following infection by the phloem restricted mollicutes Spiroplasma citri or the stolbur phytoplasma (14, Jagoueix-Eveillard, S., Tarendeau, F., Guolter, K., Danet, J. L., Bové, J. M., and Garnier, M., unpublished data).

Four of these cDNAs were used as probes in northern blot analysis to test the expression of the corresponding genes in C. roseus plants, 4 months post-inoculation with $X$. fastidiosa strain 9a5c. By sequence comparisons, these genes were shown to correspond respectively to a sterol-C-meth- 
yltransferase, a transketolase-like protein, subunity III of the photosystem I and a desiccation protectant protein. All four genes were down regulated following infection by $S$. citri or the stolbur phytoplasma (14, Jagoueix-Eveillard, S., Tarendeau, F., Guolter, K., Danet, J. L., Bové, J. M., and Garnier, M., unpublished).

In the case of the plants infected with $X$. fastidiosa 9a5c, as shown on Fig. 4, the gene coding for sterol-C-methyltransferase (gene Sc I) was found to be repressed, the

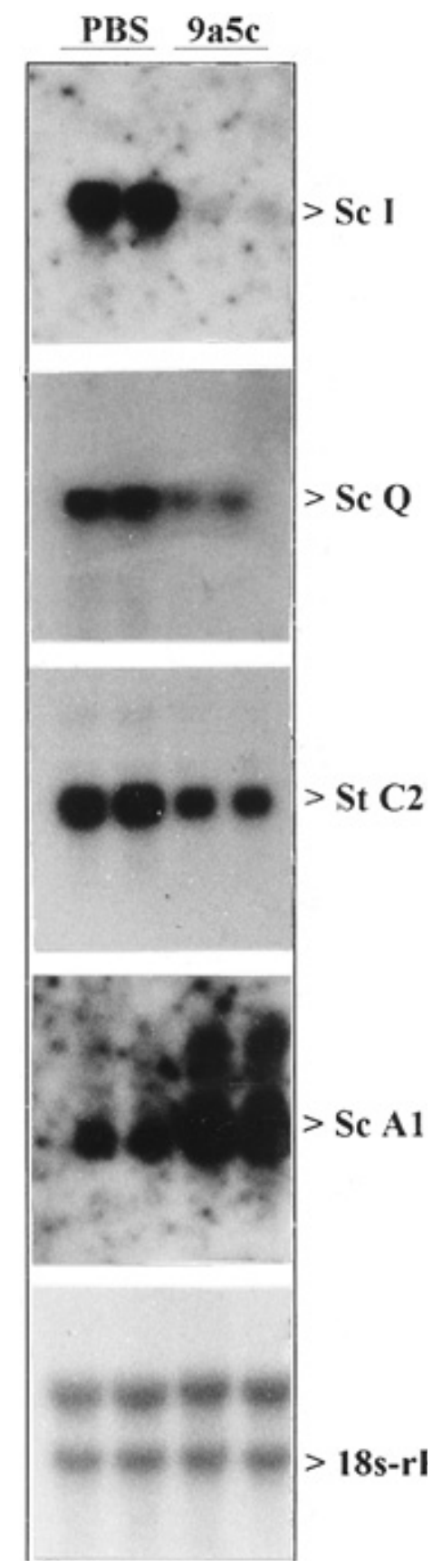

Fig. 4. Northern blot analysis of the expression of the host genes Sc I, Sc Q, St C2 and Sc A111 in healthy (phosphate-buffered saline-mock inoculated) or diseased Catharanthus roseus plants infected with $9 \mathrm{a} 5 \mathrm{c}-8$. Hybridization with 18s-rRNA probe indicates that the samples were equally loaded. genes coding for transketolase (gene Sc Q) and subunity III of photosystem I (gene St C2) were down regulated, while the gene coding for the desiccation protectant protein (gene Sc A11-1) was up-regulated. The down regulation of gene Sc I involved in sterol synthesis and genes Sc Q and St $\mathrm{C} 2$ involved in sugar transport and photosynthesis respectively, could be related to the symptoms of stunting and chlorosis often observed on periwinkle plants infected with vascular restricted pathogens. The up-regulation of the Sc A11-1 gene could be the result of the water stress induced by $X$. fastidiosa in the plants. The kinetics of the expression of the genes Sc I, Sc Q, St C2 and Sc A11-1 will be further evaluated in $C$. roseus plants infected with $X$. fastidiosa in order to establish the correlation of their expression patterns with the development of disease symptoms.

\section{ACKNOWLEDGMENTS}

This work was supported by Fundo de Defesa da Citricultura (Fundecitrus), Institut National de la Recherche Agronomique and a fellowship (to P. Monteiro) from CNPq/RHAE, Institutional Project 610042/98-0. We thank S. Duret for propagating strain $9 \mathrm{a} 5 \mathrm{c}$ and $\mathrm{A}$. Purcell and H. Feil for sharing important information regarding the cultivation and plant inoculations with $X$. fastidiosa.

\section{LITERATURE CITED}

1. Banks, D., Albibi, R., Chen, J., Lamikanra, O., Jarret, R. L., and Smith, B. J. 1999. Specific detection of Xylella fastidiosa Pierce's disease strains. Curr. Microbiol. 39:85-88.

2. Beretta, M. J. G., Barthe, G. A, Ceccardi, T. L., Lee, R. F., and Derrick, K. S. 1997. A survey for strains of Xylella fastidiosa in citrus affected by citrus variegated chlorosis and citrus blight in Brazil. Plant Dis. 81:1196-1198.

3. Beretta, M. J. G., Harakawa, R., Chagas, C. M., Derrick, K. S., Barthe, G. A., Ceccardi, T. L., Lee, R. F., Paradela, O., Sugimori, M., and Ribeiro, I. A. 1996. First report of Xylella fastidiosa in coffee. Plant Dis. 80:821.

4. Chang, C. J., Garnier, M., Zreik, L., Rossetti, V., and Bové, J. M. 1993. Culture and serological detection of the xylem-limited bacterium causing citrus variegated chlorosis and its identification as a strain of Xylella fastidiosa. Curr. Microbiol. 27:137-142.

5. Chen, J., Chang, C. J., Jarret, R. L., and Gawel, N. 1992. Genetic variation among Xylella fastidiosa strains. Phytopathology 82:973-977.

6. Chen, J., Lamikanra, O., Chang, C. J., and Hopkins, D. L. 1995. Randomly amplified polymorphic DNA analysis of Xylella fastidiosa Pierce's disease and oak scorch pathotypes. Appl. Environ. Microbiol. 61:1688-1690.

7. Contreras, J. del V. 1992. Pecosita ou falsa mancha grasienta na Argentina. Laranja e Cia. (Matão) 31:6.

8. Davis, M. J., Raju, B. C., Brlansky, R. H., Lee, R. F., Timmer, L. W., Norris, R. C., and McCoy, R. E. 1983. Periwinkle wilt bacterium: Axenic culture, pathogenicity and relationships to other gram-negative, xyleminhabiting bacteria. Phytopathology 73:15101515.

9. Ferreira, H., Neto, J. R., Gonçalves, E. R., and Rosato Y. 1999. A simplified subtractive hybridization protocol used to isolate DNA sequences specific to Xylella fastidiosa. Microbiology 145:1967-1975.

10. Freitag, J. H. 1951. Host range of the Pierce's disease virus of grapes as determined by insect transmission. Phytopathology 41:920934.

11. French, W. J., and Kitajima, E. W. 1978. Occurrence of plum leaf scald in Brazil and Paraguay. Plant Dis. Rep. 62:1035-1038.

12. Garnier, M., Chang, C. J., Rossetti, V., and Bové, J. M. 1993. Citrus Variegated Chlorosis: Serological detection of Xylella fastidiosa, the bacterium associated with the disease. Pages 301-305 in Proc. 12th Conf. Int. Organ. Citrus Virol., P. Moreno, J. V. da Graça, and L. W. Timmer, eds. Dep. Plant Pathol., University of California, Riverside.

13. Hopkins, D. L. 1989. Xylella fastidiosa: xylem-limited bacterial pathogen of plants. Annu. Rev. Phytopathol. 27:271-290.

14. Jagoueix, S., Guolter-Verdier, K., Tarendeau, F., Danet, J. L, Bové, J. M., and Garnier, M. 1999. Interaction of mollicutes with their host plant: Differential expression of plant genes following infection by mollicutes. Page 181 in Proc. 9th Int. Con. Molecular PlantMicrobe Interact., W. Augustijn, and $\mathrm{H}$. Augustijn, eds. Amsterdam.

15. Kitajima, E. W., Bakaracic, M., and Fernandez-Valiela, M. V. 1975. Association of rickettsia-like bacteria with plum leaf scald disease. Phytopathology 65:476-479.

16. Li, W. B., Zreik, L., Fernandes, N. G., Miranda, V. S., Teixeira, D. C., Ayres, A. J., Garnier, M., and Bové, J. M. 1999. A triply cloned strain of Xylella fastidiosa multiplies and induces symptoms of citrus variegated chlorosis in sweet orange. Curr. Microbiol. 39:106-108.

17. Lima, J. E. O., Miranda, V. S., Hartung, J. S., Brlansky, R. H., Coutinho, A., and Carlos, E. F. 1998. Coffee leaf scorch bacterium: axenic culture, pathogenicity and comparison with Xylella fastidiosa of citrus. Plant Dis. 82:9497.

18. McCoy, R. E., Thomas, D. L., Tsai, J. H., and French, W. J. 1978. Periwinkle wilt, a new disesase associated with xylem delimited rickettsia-like bacteria transmitted by a sharpshooter. Plant Dis. Rep. 62:1022-1026.

19. Paradela-Filho, O., Sugimori, M. H., Ribeiro, I. J. A., Garcia, Jr. A., Beretta, M.J.G., Harakawa, R., Machado, M. M., Laraneira, F. F., Rodriges Neto, J., Beriam, L. O. S. 1997. Occurrence of Xylella fastidiosa in coffee plants in Brazil. Summa Phytopathol. 23:4649.

20. Pooler, M. R., and Hartung, J. S. 1995. Genetic relationships among Xylella fastidiosa strains causing citrus variegated chlorosis. Curr. Microbiol. 31:134-137.

21. Pooler, M. R., and Hartung, J. S. 1995. Specific PCR detection and identification of $X y$ lella fastidiosa strains causing citrus variegated chlorosis. Curr. Microbiol. 31:377381.

22. Purcell, A. H. and Hopkins, D. L. 1996. Fastidious xylem-limited bacterial plant pathogens. Annu. Rev. Phytopathol. 34:131-151.

23. Purcell, A. H., Saunders, S. R., Hendson, M., Grebus, M. E., and Henry, M. J. 1999. Causal role of Xylella fastidiosa in oleander leaf scorch disease. Phytopathology 89:53-58.

24. Rosato, Y. B., Neto, J. R., Miranda, V. S., Carlos, E. F., and Manfio, G. P. 1998. Diversity of a Xylella fastidiosa population isolated from Citrus sinensis affected by citrus variegated chlorosis in Brazil. System. Appl. Microbiol. 21:593-598.

25. Rossetti, V., Garnier, M., Bove, J. M., Beretta, M. J. G., Teixeira, A. R. R., Quaggio, J. A., and de Negri, J.D. 1990. Présence de bactéries dans le xylème d'orangers atteints de chlorose variégée, une nouvelle maladie des agrumes au Brésil. C.R. Acad. Sci. 310:345-349. 
26. Simpson, A. J. G., Reinach, F. C., Arruda, P., Abreu, F. A., Acencio, M., Alvarenga, R., Alves, L. M. C., Araya, J. E., Baya, G. S., Baptista, C. S., Barros, M. H., Bonaccorsi, E. D., Bordin, S., Bove, J. M., Briones, M. R. S., et al. 2000, The genome sequence of the plant pathogen Xylella fastidiosa. Nature 406:151157.

27. Ueno, C., Funada, K., and Yorinori, M. A. 1998. First report of Xylella fastidiosa on Catharanthus roseus in Brazil. Plant Dis. $82: 712$.
28. Wells, J. M., Raju, B. C., Hung, H-Y., Weisburg, W. G., Mandelco-Paul, L., and Brenner D. J. 1987. Xylella fastidiosa gen. nov., sp. nov: gram-negative, xylem-limited, fastidious plant bacteria related to Xanthomonas spp. Int. J. Syst. Bacteriol. 37:136-143. 